\title{
The Use of Banten-Dialect Javanese Language as the Identity Marker of Banten Society Viewed from Gender Perspective
}

\author{
Siti Suharsih \\ University of Sultan Ageng Tirtayasa Banten \\ e-mail: siti.suharsih@yahoo.co.id
}

\begin{abstract}
:
Given the reality of language diversity in Banten and juxtaposed with the differences in language behavior between men and women, the researcher directly examined the pattern of Banten-Dialect Javanese Language associated with gender in the community of Gowok Village, Sukajaya, Curug District, Serang City. This study aimed to describe the patterns of Banten-Dialect Javanese Language use in the family and neighborhood domains viewed from gender perspective. To achieve the objectives, this study used a qualitative approach. A qualitative approach was used to describe the patterns of Banten-Dialect Javanese Language in two domains, namely family and neighborhood, and describe how gender can distinguish the use of language in the two domains. The Source of data of this research were the speakers of Banten-Dialect Javanese Language in Gowok Village, Curug District, Serang City, and the determination of informants was done by snowball sampling technique. The method used to collect the data of this research was survey method. To obtain the data from large source of data, the researcher used data collection techniques through a written questionnaire
\end{abstract}

Keywords: Dialect, identity marker, gender 


\section{Introduction}

Self-representation through language is one of the important variables in sociolinguistic studies. Self-representation can be influenced by the demographic and social aspects of language users. Economics, politics, and urbanization are the demographic factors that have a powerful influence on the selection and use of a language. Another important factor that can strengthen the reason for choosing and using language is the social aspect. Level of education, occupation, age, and gender are the components of social factors that influence the pattern of language usage.

Studies on gender and language use have been widely practiced by language sociologists and linguistic anthropologists. The results of the study of gender and the use of language show that men and women use language in different ways. Eckert and McConnel Ginet (1992: 90) revealed that the language of women reflects more of themselves as conservative, prestigious, vulnerable, emotional, sensitive to others, and a sense of solidarity. On the other hand, men reflect on themselves as strong, competitive, independent, and full of control. In line with the topic of language use and gender, some studies conducted to reveal the language differences between men and women. Murdianti (2013) put her focus on her study about "Women's Language as the Main Character in Jane Austin's Novel: Pride and Prejudice”. In her study, Murdianti tried to figure out the language used by women in a novel. Meanwhile, few linguistics studies concerned in explaining the relationship among gender, language use and language maintenance. As one of sociolinguistics variables, Gunarwan (1996); Willian (2006) found that gender did not give significant differences in language use in term of language maintenance. In the other hand, Rokhman's finding (2004) showed that Banyumas community differentiate their code choice based on sex.

From the recent study about language and gender, language differences between men and women can distinguish their role in maintaining their social and group identity in society. Domination of women in the domestic sphere provides space for teaching children to behave in language rather than men. Although women's role is more dominant in the domestic field, women have more opportunity to interact with other people who have different jobs than men (e.g. when they go to a shop or to school, they will interact with different people from different occupations). Conversely, men tend to interact with people who have the same kind of job as themselves.

Given the reality of language diversity in Banten province and juxtaposed with differences in language behavior between men and women, the researcher directly examined the patterns of Banten-Dialect Javanese Language (Bahasa Jawa Dialek Banten, henceforth $B J D B$ ) associated with gender in the community of Sukajaya Village, Curug District, Serang City. As one of the pockets of $B J D B$ users in Banten province, the people of Sukajaya are faced with the challenge of maintaining the $B J D B$ as an identity marker or even shifting the mother tongue with the dominant language used by the wider community as a consequence of the multilingual community. If the villagers of Sukajaya choose the dominant language that controls 
the economy and politics, it is not impossible that it hampers the efforts to preserve the values of local wisdom in the $B J D B$.

\section{Literature Review}

This section highlights some theories as a framework for analyzing data. The theories cover the discussion of language and gender, language use and language maintenance.

\subsection{Language and Gender}

Gender definitions are often differentiated by sex. Sex refers to the biological and anatomical differences between men and women. Gender discusses the differences in psychology, social, and culture between men and women (Giddens, 1989: 158). In the sociolinguistic context, the terminology between sex and gender is not too questionable. In some sources (Hudson, 2005, Coulmas, 2012) they used the term sex as a reference to the concept of gender. Associated with the definition of gender, Lewotin (1982: 142) defines gender as the result of social norms, power structures, and social roles. Stolcke (1993: 19) adds that gender consists of categories constructed by social construction by instituting culture and social status so that male dominance over women will look more natural.

The research of gender and language in the sociolinguistic context is divided into several paradigms (Wodak \& Benke, 2000: 132-135). William Labov began his first language and gender research to examine the relationship between gender and phonology. In doing his research, Labov used social interviews. Labov's results showed that pronunciation can be influenced by sex. A person's social status can be reflected in the way one speaks and is shown to the choice of words and the sound of certain words. The results shown by Labov inspire other linguists so that for decades many researches trends are following the Labov paradigm. One of the people who have the same frame of mind as Labov is Trudgill (1972).

Through the new approach, Lesley and James Milroy present qualitative methods for listing gender and language research. This qualitative period began in 1980 with a micro-social research orientation of the use of language, social networks, and the matters relating to other linguistic branches. It can be argued that Milroy emphasized the importance of context sensitivity. Milroy's research results showed that the tendency of men and women in speaking was indeed different. Women used standard language patterns rather than men. Meanwhile, men use the local language more in the group. In addition to using both quantitative and qualitative methods, the latest trend in researching language and gender is by ethnography and social parameters (Wodak \& Benke, 2000: 141).

\subsection{Language Maintenance}

The study of the language maintenance and shift was first conceived by Fishman in the 1960s through his research on mother tongue in America. Furthermore, in his book "The Sociology of Language" (1972), Fishman discussed a language that was elaborated through a sociological approach. In this book Fishman distinguished between the descriptive and dynamic language sociology. The descriptive sociology 
of language focused on the merits of communication emphasized on the social context of a linguistic society. The dynamic sociology of language discussed the scale of change that occurs in the language community with its language. In other words, the topic of language maintenance and shift is a dynamical language sociology study.

Language maintenance and shift are two things that are related to one another. For this matter, Fishman (1964: 32) explained that:

The study of language maintenance and shift is concerned with the relationship between degree of change (for degree of stability)in language usage patterns, on one hand, on the other hand, and on going psychological, cultural, and social processes, on the other hand, in population utilized more than one speech variety for intragroup or for intergroup purposes.

From Fishman's explanation of the concept of language maintenance and shift, it is understood that language shifts are recognized through a change in language usage habits through psychological, social, and cultural processes in a multilingual society. In contrast, language maintenance is a stable condition of society in using their language in a growing society.

Hamers (1993: 158) expressed his opinion on the definition of language maintenance. According to him, a language can survive if the language is still used by speakers who are bilingual. Referring to Hamers' opinion, he emphasized the maintenance aspect of the language speakers. Although he is a bilingual speaker but if he is still able to use two or more languages he master, then the speaker is considered to have retained the language.

On the other hand, Fishman saw the factor that most affects a language was maintained or not is family. Fishman called the family as an initial process of language maintenance. In the family, parents transmit to the next generation so that the extinction chain of language can be avoided (Ostler, 2011: 315). Although in a multilingual society or in the pressures of a very strong language shift, but if people still use the mother tongue in their families, it can be said that society has made efforts to maintain the language (Holmes, 2008: 63). Some opinions of the experts who approve families have an important role in maintaining the mother tongue, are supported by Edward (1985: 50). According to him, the family becomes an important determinative factor in the survival or the absence of a language, including when parents do not continue the first language heritage to their children.

\subsection{Language Choice and Language Use}

The factors that determine the choice of language include the person to whom the speaker is speaking, the social context of the conversation, and the topic of the conversation (Holmes, 2008: 21; Spolsky, 2003: 34). Holmes agreed with Fishman's view that the social factors that make up the choice of language become a construct of language in a multilingual society. The construction is known as the domain of language usage. According to Fishman (1972: 43), the domain of language usage is 
used to investigate the use of language closely related to social factors, namely the relationship of roles, location and topic of conversation. In other words, the domain of language usage is the place of language use or linguistic activity in the particular place. In the home, for example, refers to a place that has a role relationship for each family member, such as mother, father, son, grandmother, grandfather, baby, and other relatives. The relationship of this role will be influenced by the topic of each family member's activity, such as the topic of family, food, or household affairs. If the topic of the activity is different, then family members may use different languages. The domain of language usage may differ from one language community to another, but Fishman mentioned several domains that show the use of language in multilingual communities, for instance family, school, work, friendship, and religion.

If each domain requires the speakers to choose the appropriate language, then the languages will have different positions and functions. Fishman (1972: 44) provided examples in the domain of education (at school), religion (at church), in the workplace (office), the language used serves as the official language and has a high level compared to the language used in the family, neighborhood, and jobs for the lower classes. When the speaker is at home, he will use his mother tongue to communicate with other family members. Conversely, when a speaker is at school or at work, he or she will use a formal, institutionalized or formalized language.

\section{Research Methodology}

Research method deals with the methodology used from obtaining data to analyzing data.

\subsection{Research design}

To get an answer of the question addressed, this research employed a qualitative approach. A qualitative approach was used to observe and describe the pattern of $B J D B$ in two domains, namely the family and neighborhood.

As explained by Neuman (1997: 14) that in addition to trying to construct reality and understanding its meaning, the qualitative approach focused on events interactively, making authenticity as the main key, limited by situation, few cases and subjects, using thematic analysis, and involving researchers in series of the research.

\subsection{Data Sources}

Data source was all speakers of $B J D B$ in Sukajaya Village, Curug District, Serang City. In general, Sukajaya is one of the villages that belongs to the administrative area of Serang City. Serang area can generally be seen through the following map. 


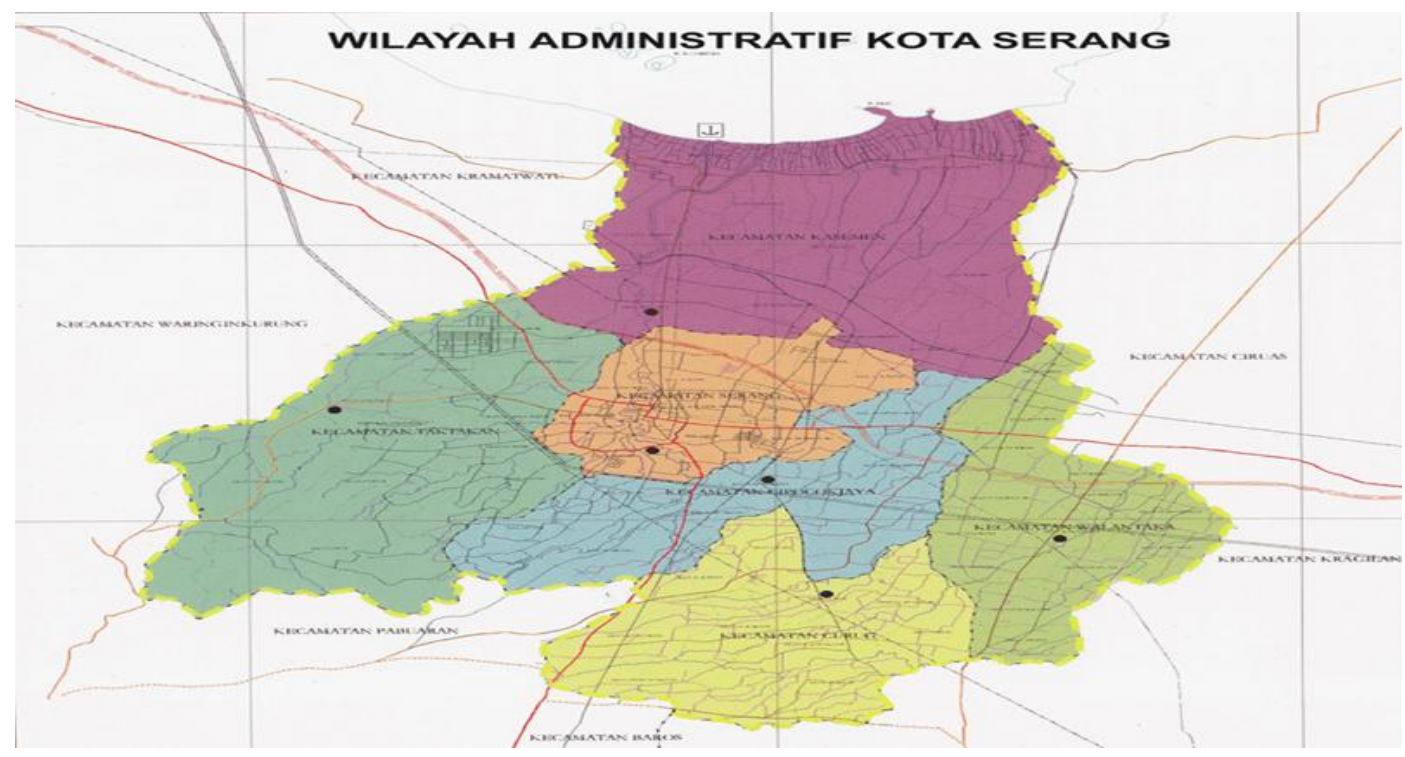

Figure 1: Serang City Map

The map figures out the administrative area of Serang has six districts, namely Serang, Walantaka, Kasemen, Cipocok Jaya, Taktakan, and Curug. Gowok is the name of one of the villages in Sukajaya, Curug District.

The determination of samples as the respondents was done by snowball sampling technique. The snowball sampling technique is a sampling technique that is assisted by a key informant. Furthermore, the key informants will provide information to the researcher everyone that can be the next informants in accordance with the requirements proposed by researcher (Subagyo, 2006: 13).

In determining the informants, the researchers set the following conditions:

1. Indigenous people, which are born in the region of Banten;

2. Men and women;

3. At least 17 years old and maximum 60 years old

4. It is a speaker of $B J D B$;

5. Can speak Bahasa Indonesia;

6. Having complete / normal speech apparatus;

7. Willing to be interviewed

From the results of the data source through the snowball sampling technique, the researcher got 50 respondents who meet the criteria as the respondents.

\subsection{Data Description}

In some sources, the $B J D B$ is written as Banten-Dialect Javanese Language (dialek Jawa Banten) only. The use of Banten-Dialect Javanese Language is found in writings of Patmadiwiria (1977) and Hudari (1977). In this case, Iskandarwassid (1985: 6) considered it not as an issue. The most important thing is that this language refers to speakers and environments that use the Javanese language in the 
region of Banten so he chose to use the $B J D B$. For the purposes of this research, the researcher used the name of $B J D B$ as used by Iskandarwassid.

There are two sources that write about the $B J D B$, the book written by Iskandarwassid, et. al. (1985) entitled "Struktur Bahasa Jawa Dialek Banten" (The Structure of the Banten-Dialect Javanese Language) and "Kamus Dialek Jawa Banten" (The Dictionary of the Banten-Dialect Javanese Language) written by Munadi Patmadiwiria in 1977. These two sources mentioned the differnt number of $B J D B$ phonemes. The dictionary written by Munadi Patmadiriwiria mentioned that $B J D B$ has 26 phonemes divided into 6 vowels and 20 consonants. Iskandarwassid divided the $B J D B$ phonemes into 24 phonemes, consisting of 6 vowels and 18 consonants. Two consonants that are not classified as sounds in $B J D B$ are glottal (?) and / $\mathrm{f} /$. He reasoned that glottal sound is used by Javanese speakers generally, but the $B J D B$ does not use the sound.

The $B J D B$ has language level like Javanese language in general but not as tight as Javanese language. $B J D B$ only recognizes two levels of language, pasaran (lowest level) and bebasan (the highest level).

The $B J D B$ is usually used informal situations that are influenced by the underlying social context. For example, when a teacher telling students to do something or while talking to an old friend. Conversely, when the student communicates with the teacher, the student uses the bebasan as a form of respect to the respected person.

\subsection{Research Sites}

The research location is centered on Gowok, Sukajaya Village, Curug District, Serang City. Gowok is one village under the Sukajaya Village in which most of the people still use the $B J D B$ to interact.

Gowok village is in the central government of Banten Province. To reach this location, it takes only 5 minutes because the distance from the central government is about 300 meters. The selection of this village is related to the heterogeneous community because it is adjacent to the central government. The condition of the community that often interacts with the outsiders show an interesting linguistic situation studied, because the pressure of outsiders will be far greater and more than a homogeneous society.

The boundaries of Sukajaya Village ar North adjacent to Karundang Village, Cipocok District;

1. The southern borders directly with the Sukawana Village, Curug District;

2. The east borders directly with Cilaku Village, Curug District;

3. The west is directly adjacent to Sindangsari Village, Pabuaran District.

The Sukajaya Urban Village has a total area of $231.3 \mathrm{Ha}$, with land use for settlements $(75.1 / \mathrm{ha} / \mathrm{m} 2)$ and used for offices $(62.5 / \mathrm{ha} / \mathrm{m} 2)$. Topographically, Sukajaya is located in an office area, and Gowok Village is a village close to Banten Province office environment. 
The potential of the human resources is indicated by the number of men as many as 2,272 people and the number of women as many as 2,090 people with the largest livelihood of the population is on the farmers (562 people) and traveling traders (202 people). The rest of the people worked as ranchers, private employees, civil servants, fishermen, and TNI/POLRI. The biggest religion is Islam (4,807 people), while the other religion is Catholics which is followed by 2 people.

The workforce is spread at the age of 18-56 years old, with 457 men, and the unemployed population in that age range is 125 men and 56 women. When looking at the distribution of working population, men still dominate over women.

\subsection{Data Collection Method}

The method used to collect the data was the survey method. This method was used to collect and analyze the social data through a very structured and detailed questionnaire (Wiseman \& Aron, 1970: 37). The survey method is useful for extracting data from large populations. To obtain the data from large populations, the researcher used data collection techniques through structured interview instruments (written questionnaires) (Gunarwan, 2002; Schilling, 2013).

In spreading the list of questionnaires, the researcher used direct techniques (face to face). Schilling (2013: 67) encouraged the language researchers to spread the questionnaire directly and verbally. Besides being able to control who becomes the respondents, the questionnaires which are verbally asked can make the respondents more relax while filling in the data and the confusing matters can be clarified immediately.

This question list was divided into two parts. The first part contains the identity of the respondent. The respondents filled out four questionnaires according to the options provided. The second part contains questions about the use of the $B J D B$. The use of $B J B D$ is based on the choice of language influenced by the relation of roles and situations that occur when the respondent communicates in two domains, namely the family domain and neighborhood domains.

\subsection{Data Analysis Technique}

Based on the data obtained through the questionnaire technique, the researcher performed the data analysis qualitatively. The results of respondents' answers were described descriptively by linking them using the theories.

\section{Findings}

This chapter revealed the data findings from the distributed questionnaire. The displayed data showed the use of BJDB in family and neighborhood domain by female and male group. Data also represented the use of language based on age grade in each different gender.

\subsection{The use of $B J D B$ in Family Domain among Female Group.}

Based on the questionnaire distributed to 27 women in Gowok Village, BJDB speakers were found with different age groups. The 27 respondents were in five age 
groups, which are in the age of 17-20, 21-30, 31-40, 41-50 and 51-60 years old. To see the patterns of the usage, those five female groups are presented respectively.

\subsubsection{Female Group between 17-20 Years Old}

From the 27 respondents who successfully encountered, six of them are in the 17-20 year in age range. In this age range, three people are students, two are housewife and one is a servant. From the overall data in the 17-20 year age range, it can be seen the use of $B J D B$ in the family domain as follows.

Table 1. The use of $B J D B$ among female group between 17-20 years old

\begin{tabular}{|l|l|l|}
\hline Family Relationship & $\boldsymbol{B J D B}$ & Other Language \\
\hline With Father & $100 \%$ & \\
\hline With Mother & $100 \%$ & \\
\hline With Husband* & $100 \%$ & \\
\hline With Children & $100 \%$ & \\
\hline With Relatives (uncle, aunt, nephew, etc) & $100 \%$ & \\
\hline With Servant (if applies) & - & \\
\hline
\end{tabular}

Taking into account that the user of $B J D B$ in the 17-20 year age group found that almost all respondents use $B J D B$. In some married females, they also used $B J D B$ when communicating with their husbands and children. In the relationship of respondents with servant, found the data was empty. This indicated that the female group between 17-20 years old did not have servant.

\subsubsection{Female Group between 21-30 Years Old}

A total of nine respondents belong to the age range 21-30 years. In this age range, the respondents are out of school, but they are already married, and some are already employed. Their occupation in this age range is quite diverse, that are, besides being housewife, they work outside the home as employee, honorary worker, labor, and enterpreneur. The intensity of $B J D B$ usage in the family domain in this age group can be illustrated in the following table.

Table 2. The Use of $B J D B$ among female group between 21-30 years old

\begin{tabular}{|l|l|l|}
\hline Family Relationship & $\boldsymbol{B J D B}$ & Other Language \\
\hline With Father & $100 \%$ & \\
\hline With Mother & $100 \%$ & \\
\hline With Husband* & $100 \%$ & \\
\hline With Children & $100 \%$ & \\
\hline With Relatives (uncle, aunt, nephew, etc) & $100 \%$ & \\
\hline With Servant (if applies) & - & \\
\hline
\end{tabular}

Based on the questionnaire results, the age group of 21-30 showed the percentage of $\%$ in the use of $B J D B$ when talking with father, mother, husband, children, and relatives. Similar to the age group of 17-20, the females who work as housewife used $B J D B$ to communicate with their husbands and children. Interestingly, it was 
found in the age group that some work outside of home. By the time they return to home, they still use $B J D B$ to communicate with the family.

\subsubsection{Female Group between 31-40 Years Old}

From 27 female respondents, five of them belong to this group. They have different jobs one another; that are housewife, businewoman, and labor.

Table 3. The use of BJDB among female group between 31-40 years old

\begin{tabular}{|l|l|l|}
\hline Family domain & BJDB & Other Language \\
\hline At Home & $100 \%$ & \\
\hline With Father & $100 \%$ & \\
\hline With Mother & $100 \%$ & \\
\hline With Husband/Wife & $90 \%$ & $10 \%$ \\
\hline With Relatives (uncle, aunt, nephew, etc) & $100 \%$ & \\
\hline With Servant (if applies) & - & \\
\hline
\end{tabular}

From those findings above, almost all respondents use $B J D B$ in their family domain. It means that when they communicate with their father, mother, and relatives, they use $B J D B$. For those who have married, one respondent uses other language (Indonesian language) when she communicates with her husband. Such a circumstance is due to intra-cultural marriage, so that she prefers to use the shared language. Although using Indonesian language to her husband, the respondent still uses $B J D B$ to communicate with her children. The data show that when she is at home, she tends to use more than one language depending on the interlocutor they are speaking to.

\subsubsection{Female Group between 41-50 Years Old}

From the obtained survey data, there were three respondents who belong to the age group of 41-50 years old. Considering the age group, most respondents are middleaged women who have had many experiences. Three of them are housewife and the other one is a enterpreneur.

These three respondents stated that they use $B J D B$ when they are at home and communicating with family members and relatives. The intensity of its use can be see in the following table.

Table 4. The use of $B J D B$ among female group between 41-50 years old

\begin{tabular}{|l|l|l|}
\hline Family Relationship & $\boldsymbol{B J D B}$ & Other Language \\
\hline At Home & $100 \%$ & \\
\hline With Father & $100 \%$ & \\
\hline With Mother & $100 \%$ & \\
\hline With Husband/Wife & $100 \%$ & \\
\hline With Relatives (uncle, aunt, nephew, etc) & $100 \%$ & \\
\hline With Servant (if applies) & - & \\
\hline
\end{tabular}




\subsubsection{Female Group between 51-60 Years Old}

The age group of 51-60 years old is where language has been well articulated. The respondents within this age group are considered to have positive attitude upon their local language. From four respondents in this category, three of them are housewife, while the other one is a labor.

Table 5. The use of $B J D B$ among female group between 51-60 years old

\begin{tabular}{|l|l|l|}
\hline Family Relationship & $\boldsymbol{B J D B}$ & Other Language \\
\hline At Home & $100 \%$ & \\
\hline With Father & $100 \%$ & \\
\hline With Mother & $100 \%$ & \\
\hline With Husband/Wife & $100 \%$ & \\
\hline With Relatives (uncle, aunt, nephew, etc) & $100 \%$ & \\
\hline With Servant (if applies) & - & \\
\hline
\end{tabular}

Similar to the other age groups, the respondents in this group still keep using $B J D B$ to communicate with their father, mother, husband, children, and relatives. Reflecting from the spread of respondents divided into five age groups, it can be seen that almost $100 \%$ of the respondents use $B J D B$ when communicating with family members, that are father, mother, children, husband, and relatives. Only one respondent prefers to use Indonesian language to communicate with her husband.

The use of $B J D B$ in family domain was not influenced by the variety of jobs, whether the respondents work outside of home or as housewife. Those who work as housewife and those who work as employee, honorary teacher, labor, or enterpreneur still use $B J D B$.

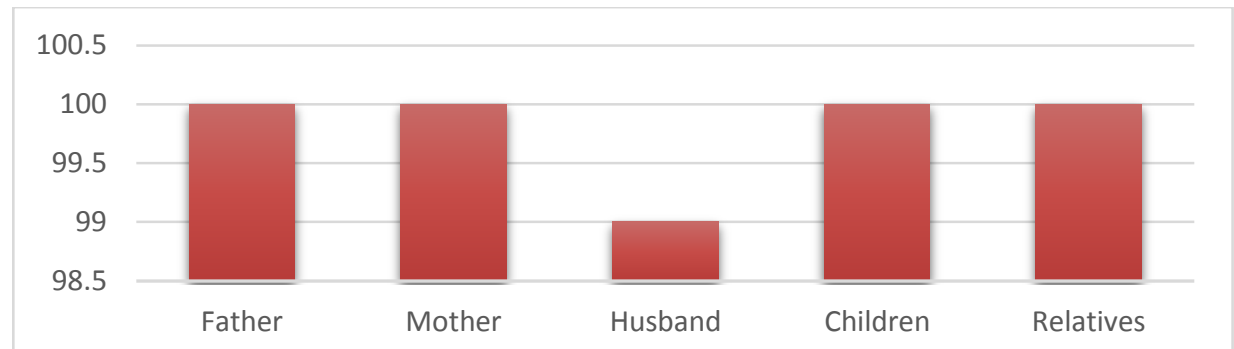

Figure 2. The Distribution Diagram on the Use of $B J D B$ in Family Domain

\subsection{The Use of $B J D B$ in Family Domain among Male Group}

Based on the obtained data, male respondents had fewer number than female ones. The survey results show that the number of returned questionnaires from this group was 22. Similar to the female group, male group was divided into five age groups. 


\subsubsection{Male Group between 17-20 Years Old}

From the 22 questionnaires for male group, three of them are in the age group of 1720 years old. Two respondents are students, while the other one is an labor. The following table shows the percentage of intensity in using $B J D B$ in family domain.

Table 6. The use of $B J D B$ among male group between 17-20 years old

\begin{tabular}{|l|l|l|}
\hline Family Relationship & $\boldsymbol{B J D B}$ & Other Language \\
\hline At Home & $100 \%$ & \\
\hline With Father & $100 \%$ & \\
\hline With Mother & $100 \%$ & \\
\hline With Husband/Wife & $100 \%$ & \\
\hline With Relatives (uncle, aunt, nephew, etc) & $100 \%$ & \\
\hline With Servant (if applies) & - & \\
\hline
\end{tabular}

Based on the table above, three respondents has got $100 \%$ on the use of $B J D B$ in family domain when communicating with father, mother, children, and relatives. Because two respondents are students, only one respondent uses $B J D B$ to communicate with wife and children.

\subsubsection{Male Group between 21-30 Years Old}

The second age group is between 21-30 years old. In this category, there are six respondents answering the questionnaire on the use of $B J D B$ in family domain. Six respondents have different occupational background from students/higher students (2 respondents), enterpreneur (1 respondent) to office cleaning service (3 respondents). The following table represents the respondents' answers.

Table 7. The use of $B J D B$ among male group between 21-30 years old

\begin{tabular}{|l|l|l|}
\hline Family Relationship & $\boldsymbol{B J D B}$ & Other Language \\
\hline At Home & $100 \%$ & \\
\hline With Father & $100 \%$ & \\
\hline With Mother & $100 \%$ & \\
\hline With Husband/Wife & $100 \%$ & \\
\hline With Relatives (uncle, aunt, nephew, etc) & $100 \%$ & \\
\hline With Servant (if applies) & - & \\
\hline
\end{tabular}

From the table above, it can be seen that they still use $B J D B$ in family domain when communicating at home. It means that occupational background had nothing to do with the respondents' tendency in using the language compared to that in workplace and educational settings.

\subsubsection{Male Group between 31-40 Years Old}

There are six respondents in the age group of 31-40 years old. These six respondents have more diverse occupational background compared to the previous group; that 
are labor (2 respondents), enterpreneur (1 respondents), cleaning service (1 respondent), security (1 respondent), and civil servant ( 1 respondent).

As with the diverse occupational background of the respondents, the following table shows the use of $B J D B$ in family domain.

Table 8. The use of $B J D B$ among male group between 31-40 years old

\begin{tabular}{|l|l|l|}
\hline Family Relationship & $\boldsymbol{B J D B}$ & Other Language \\
\hline At Home & $100 \%$ & \\
\hline With Father & $100 \%$ & \\
\hline With Mother & $100 \%$ & \\
\hline With Husband/Wife & $100 \%$ & \\
\hline With Relatives (uncle, aunt, nephew, etc) & $100 \%$ & \\
\hline With Servant (if applies) & - & \\
\hline
\end{tabular}

Table 8 shows that $100 \%$ of the respondents prefer to use $B J D B$ in family domain when communicating with family members and relatives. It means that the diverse occupational background did not influence the language use at home.

\subsubsection{Male Group between 41-50 Years Old}

There are three respondents in the age group of 41-50 years old. These three respondents have the same occupational background, which is labor, and they all confirmed that the use of $B J D B$ in family domain was $100 \%$. It means that when they are at home, they use $B J D B$ to communicate with wife, children, parents, and close relatives. The following table represents the data regarding the male group of 41-50 years old.

Table 9. The use of $B J D B$ among the male group between 41-50 years old

\begin{tabular}{|l|l|l|}
\hline Family Relationship & $\boldsymbol{B J D B}$ & Other Language \\
\hline At Home & $100 \%$ & \\
\hline With Father & $100 \%$ & \\
\hline With Mother & $100 \%$ & \\
\hline With Husband/Wife & $100 \%$ & \\
\hline With Relatives (uncle, aunt, nephew, etc) & $100 \%$ & \\
\hline With Servant (if applies) & - & \\
\hline
\end{tabular}

\subsubsection{Male Group between 51-60 Years Old}

The next group is the respondents who belong to the age group of 51-60 years old. These respondents consist of four people in which three of them are labor, while the other one is enterpreneur. They confirmed that they still use $B J D B$ at home to communicate with their families.

The use of $B J D B$ at home in this age group showed that the respondents use $100 \%$ $B J D B$ in their daily communication. 
Table 10. The use of $B J D B$ among the male group between 51-60 years old

\begin{tabular}{|l|l|l|}
\hline Family Relationship & $\boldsymbol{B J D B}$ & Other Language \\
\hline At Home & $100 \%$ & \\
\hline With Father & $100 \%$ & \\
\hline With Mother & $100 \%$ & \\
\hline With Husband/Wife & $100 \%$ & \\
\hline With Relatives (uncle, aunt, nephew, etc) & $100 \%$ & \\
\hline With Servant (if applies) & - & \\
\hline
\end{tabular}

From the findings on the use of $B J D B$ within male groups, it can be concluded that they use $B J D B$ at home to all family members including parents, wife, children, and relatives.

\subsection{The use of Banten-Dialect Javanese Language in Neighborhood Domain}

Similar to the previous domain, neighborhood is another domain of using mother language. In Fishman's theory, a speaker will use mother language in family and neighborhood domains. This domain is considered to be informal, so that the official language (Indonesian language) is seldom used.

To see the real condition on the use of $B J D B$ in neighborhood domain, the researcher collected the data through a questionnaire handed to 50 respondents at Sukajaya village, Gowok residence. Those respondents are divided into 23 males and 27 females. This amount did not reflect to the level of researcher's subjectivity, rather the respondents' willingness in filling in the questionnaire.

The following data were based on the 50 respondents. For the sake of this research, the respondents are differentiated into male and female groups. Every group is reviewed based on the age range done as the previous study on the use of $B J D B$ in family domain.

\subsubsection{The Use of $B J D B$ in Neighborhood Domain among Female Group}

In neighborhood domain, the researcher asked for some questions related to the interaction patterns of the respondents around the environment. This domain refers to the respondents' interaction in their home surroundings. Thus, the concept of 'neighbor' refers to a group of society living in a nearby environment.

\subsubsection{The Use of BJDB among the Age Group of 17-20 Years Old}

In this domain, the respondents used $B J D B$ in interacting and communicating with their neighbors. Such activities include: simple greetings, greetings at different places (when meeting with the neighbors in formal settings), conversation about daily affairs and jobs.

From the obtained questionnaire results, the respondents within this group used $B J D B$ when interacting with their neighbors, either at home surroundings or at other formal settings. 
Table 11. The use of $B J D B$ among the age group of 17-20 years old

\begin{tabular}{|l|l|l|}
\hline Neighborhood Domain & $\boldsymbol{B J D B}$ & Other Language \\
\hline $\begin{array}{l}\text { Greeting neighbors at home } \\
\text { surroundings }\end{array}$ & $100 \%$ & \\
\hline $\begin{array}{l}\text { Greeting neighbors at village or } \\
\text { district offices }\end{array}$ & $100 \%$ & \\
\hline $\begin{array}{l}\text { Talking to neighbors about daily } \\
\text { activities/affairs }\end{array}$ & $100 \%$ & \\
\hline $\begin{array}{l}\text { Talking to neighbors about work } \\
\text { affairs/activities }\end{array}$ & $100 \%$ & \\
\hline
\end{tabular}

\subsubsection{The Use of $B J D B$ among the Age Group of 21-30 Years Old}

In the age group of 21-30 year old, the respondents used $B J D B$ when interacting with the people in their home surroundings. It was proved by their answers in the questionnaire.

Table 12. The use of $B J D B$ among the age group of 31-40 years old

\begin{tabular}{|l|l|l|}
\hline Neighborhood Domain & $\boldsymbol{B J D B}$ & Other Language \\
\hline $\begin{array}{l}\text { Greeting neighbors at home } \\
\text { surroundings }\end{array}$ & $100 \%$ & \\
\hline $\begin{array}{l}\text { Greeting neighbors at village or } \\
\text { district offices }\end{array}$ & $100 \%$ & \\
\hline $\begin{array}{l}\text { Talking to neighbors about daily } \\
\text { activities/affairs }\end{array}$ & $100 \%$ & \\
\hline $\begin{array}{l}\text { Talking to neighbors about work } \\
\text { affairs/activities }\end{array}$ & $100 \%$ & \\
\hline
\end{tabular}

\subsubsection{The Use of $B J D B$ among the Age Group of 41-50 Years Old}

The same findings were found on the use of $B J D B$ in the age group of 41-50 years old. In this age group, all respondents used $B J D B$ when interacting with their surroundings.

Table 13. The use of $B J D B$ among the age group of 41-50 years old

\begin{tabular}{|l|l|l|}
\hline Neighborhood Domain & $\boldsymbol{B J D B}$ & Other Language \\
\hline $\begin{array}{l}\text { Greeting neighbors at home } \\
\text { surroundings }\end{array}$ & $100 \%$ & \\
\hline $\begin{array}{l}\text { Greeting neighbors at village or } \\
\text { district offices }\end{array}$ & $100 \%$ & \\
\hline $\begin{array}{l}\text { Talking to neighbors about daily } \\
\text { activities/affairs }\end{array}$ & $100 \%$ & \\
\hline $\begin{array}{l}\text { Talking to neighbors about work } \\
\text { affairs/activities }\end{array}$ & $100 \%$ & \\
\hline
\end{tabular}




\subsubsection{The Use of $B J D B$ among the Age Group of 51-60 Years Old}

In this age group, the respondents asserted that they used $B J D B$ when greeting the neighbors in their home surroundings, meeting them at village and district offices, talking about daily and work activities.

Table 14. The use of $B J D B$ among the age group of 51-60 years old

\begin{tabular}{|l|l|l|}
\hline Neighborhood Domain & $\boldsymbol{B J D B}$ & Other Language \\
\hline $\begin{array}{l}\text { Greeting neighbors at home } \\
\text { surroundings }\end{array}$ & $100 \%$ & \\
\hline $\begin{array}{l}\text { Greeting neighbors at village or } \\
\text { district offices }\end{array}$ & $100 \%$ & \\
\hline $\begin{array}{l}\text { Talking to neighbors about daily } \\
\text { activities/affairs }\end{array}$ & $100 \%$ & \\
\hline $\begin{array}{l}\text { Talking to neighbors about work } \\
\text { affairs/activities }\end{array}$ & $100 \%$ & \\
\hline
\end{tabular}

Reflecting to the respondents' answers on the questionnaire based on the five age groups, it can be concluded that female group $100 \%$ used $B J D B$ when interacting with other people in the surroundings or other public places.

\subsubsection{The Use of $B J D B$ in Neighborhood Domain among Male Group}

Based on the questionnaire results from 23 male respondents, the researcher divided them into five age groups; similar to the female age group. After reviewing it, the use of $B J D B$ in family domain was used by all respondents in all age groups, from the age group of 17-20 to 51-60 years old. Thus, it can be concluded that all males in all age groups $100 \%$ used $B J D B$ in neighborhood domain.

From the findings, two groups of males and females used $B J D B$ in neighborhood domain. Looking at the percentage, both groups have got $100 \%$ for the category of $B J D B$ use when interacting with neighbors, either at home surroundings or outside of home surroundings.

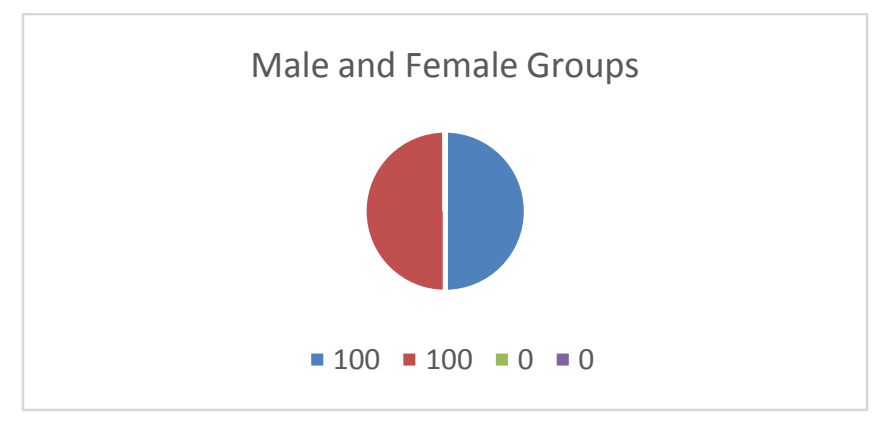

Figure 3. The use of $B J D B$ in neighborhood domain based on gender 


\section{Discussion}

The choice of using BJDB in both genders showed the process of language transmission is going to be positive. As Ostler said, "a language is maintained if speakers effectively pass it on to the next generation. If the transmission is impeded in some way, the language is endangered (2011:315) By this statement, Ostler urged that the local language would be maintained if speakers effectively used it in communication among people around him/her. Ostler also added his statement about maintaining language is that the transmission may fail because some factors: speakers do not use the language sufficiently in the learners' presence, and the motives of the speakers not to use the language or to change the language with others ones. In transmitting local language, home is considered as the basic institution functions in maintaining local language (Fishman, 1974). Supporting this idea, Edward (1985: 50) agreed that the family becomes an important determinative factor in the survival or the absence of a language, including when parents do not continue the first language heritage to their children.

From the two previous explanations, the use of $B J D B$ in family and neighborhood domains, it can be said that both males and females keep maintaining their local language in communicating with other people. Related to Ostler's statement above, it can be said that the speakers are still effectively using BJDB. By using BJDB effectively (almost $100 \%$ in two domains) showing that the transmission of local language is still running well.

Considering gender in using BJDB, the findings shows a bit difference in using BJDB between men and women. The number of female speakers who used BJDB in family domain was less than males. We can see that from the picture 1 , one female with age 31-40 used bahasa Indonesia when she interacted with her husband. This little difference found in family domain, which a female used other language when communicating with her husband, was influenced by the intra-cultural marriage. The cultural and language differences influenced the language choice employed by the female to her spouse. The difference on the language choice to the spouse and other family suggested that the female still became the sub-ordinate one from the intracultural marriage. The female's position still cannot force herself to keep maintaining her local language, although she is in the community with the same language. The sub-ordination position of women when she married with men from different region showed the power and dominance man. Deuchar (in Wodak, 200:140) mentioned that the weaker women position, the more she is forced to be polite. Standard language is one of many ways to show this difference.

However, both genders has played the role in the term of maintaining $B J D B$ as local identity. Men and women showed their habit in using $B J D B$ when they were in family or with their surroundings. It indicated that the women tendency in using less nonstandard language was not found in this research. Therefore, the recent study about language use and gender could not be generalized since every culture represented different language behavior. In Labov paradigm, the western community showed the women used more standard language than men (Wodak, 2000:133). The using of standard language among women is one effort in defining themselves in 
social norm. In contrary, women in developed country get less attention in social norm. Men are those who can lead the many things, including language use.

\section{Conclusion}

Based on the findings and data analysis, it can be concluded that: in family domain, both genders showed a different language attitude. Female respondents considered the interlocutor as the influential factor in language choice compared to male respondents; in neighborhood domain, both genders showed similar language attitude in which they used $B J D B$ when communicating with their surroundings; and gender still influenced the respondents in choosing what language should be used.

\section{References}

Asim Gunarwan. (2002). Pedoman Penelitian Bahasa. Jakarta: Pusat Bahasa Departemen nasional Jakarta.

Coulmas, Florian. (2006). Sociolinguistics: The Study of Speakers' Choices. UK: Cambridge University Press.

Eckert, Penelope. (2000). Age as Sociolingusitics Variable. Florian Coulmas (Ed). The Handbook of Sociolinguistics. (pg. 151-167).

Edwards, John. (1994). Language, Society and Identity. USA: Basil Blacwell

Fishman, Joshua A. (1972). The Sociology of Language. Massachussets: Newbury House.

Hamers, Josiane F dan Michel Hablanc. (1993). Bilinguality and Bilingualism. Cambridge University Press.

Holmes, Janet. (1992). An Introduction to Sociolinguistics. New York: Longman.

Iskandarwassid, et al. (1985). Stuktur Bahasa Jawa Dialek Banten. Jakarta: Pusat Pembinaan dan Pengembangan Bahasa.

Milroy, Lesley dan Matthew Gordon. (2003). Sociolinguistics Method and Interpretation. UK: Blackwell Publishing.

Munadi Patmadiwiria. (1977). Kamus Dialek Jawa Banten Indonesia. Jakarta: Depdikbud.

Mullany, Louise. (2007). Speech Community. In Carmen Llamas, Louise Mullany \& Peter Stockwell (Ed). The Routledge Companion to Sociolinguistics. (pg.. 84-91). New York: Routledge.

Neuman, W. Lawrence. (2003). Social Research Methods: Qualitative and Quantitative Approaches. Boston: Pearson Education, Inc.

Ostler, Nicholas. (2013). Language Maintenance, shift and endangerment. In Rajend Mesthrie (ed). The Cambridge Handbook of Sociolinguistics.(pg. 315334)

Schilling, Natalie. (2013). Sociolinguistic Fieldwork. USA: Cambridge University Press.

Spolsky, Bernard. (1998). Sociolinguistics. Hongkong: Oxford University Press.

Williams, Glyn. (1992). Sociolingusitics. A Sociological Critique. London: Routledge.

Wodak, Ruth. (2000). Gender as Sociolinguistics Variable. Florian Coulmas (Ed). The Handbook of Sociolinguistics. (Hlm 129-150). 